\title{
Somatostatin receptor imaging, therapy and new strategies in patients with neuroendocrine tumours
}

\author{
G. D. Slooter, A. Mearadji, W. A. P. Breeman*, R. L. Marquet, M. de Jong*, E. P. Krenning*† and \\ C. H. J. van Eijck \\ Departments of Surgery, ${ }^{*}$ Nuclear Medicine and $\dagger$ Internal Medicine, Erasmus Medical Centre Rotterdam, Rotterdam, The Netherlands \\ Correspondence to: Dr C. H. J. van Eijck, Department of Surgery, Erasmus Medical Centre Rotterdam, Dr Molewaterplein 40, 3015 GD Rotterdam, \\ The Netherlands (e-mail: vaneijck@hlkd.azr.nl)
}

\begin{abstract}
Background: Somatostatin receptors have been found on a variety of neuroendocrine tumours, such as carcinoids and paragangliomas, as well as on most pancreatic endocrine and breast tumours. Somatostatin receptor scintigraphy with a radionuclide-labelled somatostatin analogue, [ ${ }^{111}$ Indiumdiethylenetriaminopenta-acetic acid]octreotide, is a sensitive and specific technique for visualizing in vivo the presence of somatostatin receptors on various tumours.

Methods: Material was identified from previous review articles, references cited in original papers and a Medline search of the literature. Additional material was obtained from recently published abstracts of meetings.

Results and conclusion: Somatostatin receptor imaging of neuroendocrine tumours is essential in the diagnostic evaluation of most of these tumours. The expression of somatostatin receptors in vivo not only predicts the outcome of somatostatin analogue treatment but also opens the possibility of new therapeutic strategies. Because better information about spread of the disease can be obtained, more justifiable options for therapy can be proposed.
\end{abstract}

Paper accepted 2 August 2000

British Journal of Surgery 2001, 88, 31-40

\section{Somatostatin receptor expression}

Somatostatin (SS) is a small regulatory peptide; it was isolated in the ovine hypothalamic gland in 1973 as a growth hormone $(\mathrm{GH})$ release inhibiting factor ${ }^{1}$. SS is widely distributed in the human body and is found not only in the hypothalamus but also in various parts of the gastrointestinal tract, indicating that inhibition of $\mathrm{GH}$ is not its only function $^{2}$. Apart from its function as a neurotransmitter in the central nervous system, it also has inhibitory effects on the secretion of hormones by the pancreatic islets (insulin, glucagon) and on exocrine pancreatic function. SS also inhibits normal gastrin production, and consequently gastric acid and pepsin production ${ }^{3}$. A number of observations have suggested an antiproliferative effect of SS and its stable analogues ${ }^{4-6}$.

Critical to all these actions is the expression of SS receptors (SS-Rs) on the cell membrane. These SS-Rs

The Editors have satisfied themselves that all authors have contributed significantly to this publication subserve two functions, first to recognize the ligand and bind it with high affinity and specificity, and second to generate a transmembrane signal that evokes a biological response. Large numbers of SS-Rs are found on most tumours with amine precursor uptake and decarboxylation characteristics and neuroendocrine properties, such as carcinoids, paragangliomas, phaeochromocytomas, medullary thyroid cancers and endocrine pancreatic tumours. In addition, large numbers of binding sites with high affinity for SS are also found on breast and brain tumours, as well as on various cells of the immune system ${ }^{7-10}$. At least five different human SS-R subtypes have been cloned ${ }^{11}$. All subtypes bind SS with high affinity, while their affinities for the SS analogue octreotide differ considerably. Octreotide binds with high affinity to SS-R subtype $2\left(\mathrm{sst}_{2}\right)$ and $\mathrm{sst}_{5}$, to a lesser degree $\mathrm{sst}_{3}$, while no binding to $\mathrm{sst}_{1}$ and $\mathrm{sst}_{4}$ occurs. Other SS analogues that are in clinical use, such as BIM 23014 (lanreotide) and RC-160 (vapreotide), as well as the hexapeptide MK678, bind to three of the five SS-R subtypes, also displaying high affinity for $\mathrm{sst}_{2}$ and $\mathrm{sst}_{5}$ and moderate affinity for $\mathrm{sst}_{3}{ }^{12}$.

British Journal of Surgery 2001, 88, 31-40 
SS-R messenger RNA subtypes are widely expressed in neuroendocrine tumours, but their distribution does not necessarily correlate with SS-R subtype expression. Furthermore SS-R subtypes show a differential subcellular localization in human SS-R-positive tumours ${ }^{13}$. The majority of human endocrine pancreatic tumours, such as gastrinomas, glucagonomas, vipomas and 'non-functioning' islet cell tumours, express $\mathrm{sst}_{2}$. In vitro studies have shown that 72 per cent of insulinomas express SS-Rs. However, these are mainly sst 3 receptors, which have low affinity for octreotide ${ }^{14,15}$. Although SS-Rs have been demonstrated on exocrine pancreatic cells in experimental animals (mainly on acinar cells), neither SS-Rs nor neuroendocrine properties could be confirmed on human exocrine pancreatic adenocarcinomas ${ }^{16}$. Carcinoids, paragangliomas, phaeochromocytomas and medullary thyroid cancers all have a mixed distribution of the SS-R subtypes, but sst $_{2}$ is expressed most frequently. The presence of different combinations of SS-R subtypes may explain the variable clinical response to SS analogues and the difference in successful localization by SS-R scintigraphy (SRS) of these tumours. Metastases of SS-R-positive tumours initially express the same SS-R subtype as the primary, but loss of these receptors has been described after dedifferentiation of tumour cells or after chemotherapy ${ }^{17}$. In addition, SS-R overexpression has been identified in peritumoral veins of primary neoplasms and in veins surrounding lymph node, bone and lung metastases ${ }^{18}$.

\section{Somatostatin receptor scintigraphy}

The optimal management of patients with neuroendocrine tumours requires accurate imaging and staging. For the visualization of SS-R-positive tumours, SRS with $\left[{ }^{111}\right.$ Indium-diethylenetriaminopenta-acetic acid $\left({ }^{111} \mathrm{In}-\right.$ DTPA $\left.^{0}\right)$ ]octreotide (Octreoscan, Mallinckrodt Medical BV, Petten, The Netherlands) has been used for more than 10 years ${ }^{19,20}$. The efficacy of SRS using this agent in patients with histologically or biochemically proven endocrine pancreatic tumours or carcinoids was evaluated in a European multicentre trial ${ }^{20}$. The highest success rates were observed with glucagonomas (100 per cent), vipomas (88 per cent), gastrinomas (73 per cent), 'non-functioning' islet cell tumours ( 82 per cent) and carcinoids ( 87 per cent). Insulinomas were detected in only 46 per cent of cases owing to the low incidence of $s t_{2}$ on insulinoma cells. The low sensitivity in this study found for some tumours may be related to important differences in scanning procedures, such as the amount of radioligand administered, the duration of the acquisition and the use of single photon emission computed tomography (SPECT) ${ }^{21}$. With SPECT, in which a rotating camera is used, image reconstructions can be made similar to those of spiral computed tomography (CT). This technique gives additional visual information, especially on tumours in the liver and upper abdomen ${ }^{22}$. Twenty-five per cent more liver metastases are detected with SPECT than with planar SRS.

In a prospective study comparing the sensitivity of SRS with that of CT, magnetic resonance imaging (MRI), ultrasonography and selective angiography in the detection of primary and metastatic gastrinomas, SRS altered clinical management in 47 per cent of instances and had a superior sensitivity and specificity ${ }^{23}$ (Table 1). Cadiot et al. ${ }^{24}$ compared the results of SRS with those of conventional imaging techniques, including endoscopic ultrasonography, and with surgical findings in 21 consecutive patients with Zollinger-Ellison syndrome. SRS added complementary information to other imaging techniques, including endoscopic ultrasonography, and improved the preoperative detection of extrapancreatic gastrinomas. By combining SRS with endoscopic ultrasonography they were able to detect 90 per cent of the tumours in the upper duodenopancreatic area. SRS identified metastatic disease in 20-30 per cent of patients after all other imaging techniques had failed ${ }^{22}$. In another study of 160 patients with biologically and/or histologically proven gastroenteropancreatic tumours, including pancreatic islet cell tumours, SRS changed the surgical therapeutic strategy in 40 patients $(\text { Table } 2)^{25}$. Unsuspected liver tumours were discovered

Table 1 Imaging methods for the detection of liver metastases and extrahepatic metastases in patients with Zollinger-Ellison syndrome

\begin{tabular}{lll} 
& \multicolumn{2}{l}{ Positive result (\%) } \\
\cline { 2 - 3 } Procedure & $\begin{array}{l}\text { Extrahepatic tumour } \\
(n=80)\end{array}$ & $\begin{array}{l}\text { Liver metastases } \\
(n=24)\end{array}$ \\
\hline Ultrasonography & 9 & \\
CT & 31 & 46 \\
MRI & 30 & 42 \\
Angiography & 28 & 71 \\
CIM & 48 & 62 \\
SRS & 58 & 83 \\
SRS + CIM & 68 & 92 \\
SRS only & 20 & 96 \\
CIM only & 10 & 12 \\
\end{tabular}

Results are expressed as the percentage of the 24 patients with proven liver metastases and of the 80 patients with extrahepatic disease. Conventional imaging methods (CIM) included ultrasonography, computed tomography (CT), magnetic resonance imaging (MRI) and angiography. *Tumour detected only with somatostatin receptor scintigraphy (SRS); †tumour detected only with CIM. From reference 23 
only by SRS in seven patients, contralateral liver tumours before hepatectomy in two, and extrahepatic disease in 31. In 48 patients with histologically proven hepatic metastases of neuroendocrine tumours, including carcinoids, the present authors compared conventional imaging methods (CIM) with SRS for the detection of extrahepatic disease. CIM consisted of ultrasonography, CT of the thorax and abdomen and, when indicated, bone scanning. All patients were scanned according to a multiple spot views protocol. A minimal dose of $200 \mathrm{MBq}{ }^{111} \mathrm{In}$ and at least $10 \mu \mathrm{g}$ of peptide was administered as an intravenous bolus, and acquisition was performed 24 and $48 \mathrm{~h}$ thereafter. Acquisition time was $15 \mathrm{~min}$ and abdominal SPECT was used systematically with a triple head camera. SRS alone demonstrated 114 extrahepatic lesions in 37 patients, whereas CIM visualized only 50 extrahepatic lesions in 22 patients (Table 3).

In patients with paragangliomas, SRS provides optimal information on other potential tumour sites in the body; paragangliomas are often multicentric and asymptomatic ${ }^{26}$. For imaging of adrenal phaeochromocytomas, scintigraphy with radiolabelled metaiodobenzylguanidine (MIBG) is more accurate than SRS, since the majority of benign phaeochromocytomas are localized in the adrenal, a

Table 2 Clinical impact of somatostatin receptor scintigraphy in 160 patients with gastroenteropancreatic tumours

\begin{tabular}{lllll} 
& \multicolumn{5}{c}{ SRS classification } \\
\cline { 4 - 5 } Initial classification & Total no. & I & II & III \\
\hline I No metastases & 90 & 65 & 7 & 18 \\
II Liver metastases only & 59 & & 46 & 13 \\
III Extrahepatic metastases & 11 & & & 11
\end{tabular}

SRS, somatostatin receptor scintigraphy. From reference 25

Table 3 Detection of extrahepatic metastases: somatostatin receptor scintigraphy versus conventional imaging methods

$\begin{array}{llll} & \text { CIM negative } & \text { CIM positive } & \text { Total } \\ \text { SRS negative } & 11 & & 11 \\ \text { SRS positive } & 15 & 22 & 37\end{array}$

Imaging was carried out in 48 patients with histologically proven hepatic metastases of neuroendocrine tumours. The table shows number of patients with extrahepatic disease detected by somatostatin receptor scintigraphy (SRS) with [ ${ }^{111}$ Indium-diethylenetriaminopenta-acetic acid]octreotide or by conventional imaging methods (CIM) consisting of computed tomography, ultrasonography and bone scanning. In 15 patients extrahepatic metastases were detected with SRS only. Eleven patients were found to have no extrahepatic disease localization that is difficult to distinguish from the kidney with SRS. Furthermore, the majority of these benign lesions do not express SS-Rs. Recently, in a large European multicentre study, the sensitivity of $\left[{ }^{131} \mathrm{I}\right] \mathrm{MIBG}$ in detecting benign phaeochromocytomas was shown to be 81 per cent $^{27}$, while the detection rate with SRS is only around 25 per cent. The majority of malignant tumours ( 80 per cent), in contrast, express appropriate receptors and so SRS could be used to characterize adrenal masses suspected to be malignant ${ }^{28}$. SRS has a limited role in the management of medullary thyroid cancer. It might be useful for the detection of residual and recurrent disease after total thyroidectomy, or in patients who present primarily with metastatic disease in order to study the feasibility of performing peptide receptor radionuclide therapy ${ }^{29,30}$. To optimize the detection of metastases in patients with recurrent medullary cancer, the combination of SRS and ${ }^{99 \mathrm{~m}} \mathrm{Tc}$-radiolabelled dimercaptosuccinic acid $\left({ }^{99} \mathrm{Tc}-\right.$ DMSA) should be considered, as together they have a sensitivity of 84 per cent for the diagnosis of medullary cancer. SRS alone has a sensitivity of 29 per cent and ${ }^{99} \mathrm{Tc}-$ DMSA alone has a sensitivity of 69 per cent ${ }^{31}$.

Finally, the difference in SS-R expression between islet cell tumours, especially 'non-functioning' tumours and pancreatic duct cancers, offers the possibility of differentiating between these tumours before surgery ${ }^{32}$. This is important, as palliative surgery in patients with islet cell tumours is of value not only in relieving clinical symptoms but also in decreasing tumour burden, which might enhance the effect of medical treatment and result in improved clinical status and longer survival.

\section{Clinical use of somatostatin analogues}

Most endocrine pancreatic tumours, with the exception of insulinomas, have a malignant potential and have already metastasized at the time of diagnosis. These tumours are in general slow growing and most of the clinical distress is related to the hypersecretion of hormones, which often incapacitates the patient and causes long and repeated periods of admission to hospital. The clinical use of the SS analogue octreotide in this type of patient is of considerable help in controlling symptomatology. Debilitating diarrhoea, dehydration and hypokalaemia (vipoma) and necrolytic skin lesions (glucagonoma) can be well controlled during continuing treatment with octreotide. There is no doubt that octreotide therapy is of great benefit for most of these patients and improves their quality of life dramatically ${ }^{33}$. In selected patients with peptic ulceration and hyperplasia of fundic argyrophil cells (gastrinoma) or lifethreatening attacks of hypoglycaemia (metastatic insulinoma) octreotide may also be of therapeutic benefit ${ }^{34,35}$. 
Clinical studies in those with hormone-producing islet cell tumours have shown a close parallel between the presence of SS-Rs on the tumours and the in vivo and in vitro suppressive effects of octreotide on hormone release ${ }^{36}$. This indicates that SRS can predict a possible suppressive effect of octreotide on hormonal hypersecretion by endocrine pancreatic tumours. Although octreotide is able to inhibit gastrin release in Zollinger-Ellison syndrome, proton pump inhibitors are currently the first choice as over 80 per cent of patients are controlled by omeprazole, lansoprazole or pantoprazole. A major problem in the treatment of islet cell tumours and carcinoids with octreotide is that the inhibition of secretion of tumourrelated hormones is transient. Most patients finally become insensitive to octreotide treatment, possibly by downregulation of SS-R expression or outgrowth of SS-Rnegative clones ${ }^{6,37,38}$. The beneficial effects on clinical symptomatology in those with metastatic endocrine pancreatic tumour and carcinoids is highly variable. Increasing the dose of octreotide or intermittent administration reverses these problems in most cases. The median duration of improvement of diarrhoea and flushing attacks by octreotide in patients with metastatic carcinoid disease is over 12 months ${ }^{5}$.

In some patients with metastatic medullary thyroid cancer, continuous treatment with very high doses of octreotide may bring temporary relief. Long-term therapy with SS analogues for catecholamine-secreting (malignant) paragangliomas and phaeochromocytomas has not shown clinical benefit ${ }^{39}$.

The role of octreotide in the treatment of pancreatitis is controversial. A meta-analysis of six studies showed a significant decrease in mortality rate in patients with mild or severe disease ( 6 per cent octreotide versus 14 per cent placebo ${ }^{40}$. However Uhl et al. ${ }^{41}$ did not find a significant difference in mortality rate or complications in a large series of 302 patients with acute pancreatitis. The decrease in digestive enzyme secretion and the increase in intestinal water and electrolyte absorption caused by octreotide can be beneficial in the treatment of pancreatic and enterocutaneous fistula ${ }^{42,43}$. In elective surgery for pancreatic carcinoma or chronic pancreatitis, perioperative administration of octreotide has demonstrated its value. In a study of 246 patients who underwent pancreatic surgery, octreotide treatment reduced the incidence of death and complications compared with placebo (3 and 32 versus 6 and 55 per cent respectively) ${ }^{44}$. Finally, SS and octreotide infusion reduce portal pressure by decreasing splanchnic blood flow. Although the exact mechanisms of acute haemodynamic changes in patients with portal hypertension are unknown, there is a rationale for the use of SS and its derivatives in the control of acute oesophageal variceal bleeding ${ }^{45}$. Early infusion of SS in cirrhotic patients with acute variceal haemorrhage decreases treatment failure and mortality rates, and reduces active bleeding after sclerotherapy, thereby improving the efficacy of sclerotherapy for acute variceal bleeding episodes ${ }^{46}$.

\section{Oncological applications of somatostatin analogues}

The observation that SS inhibits the release of various peptide hormones has stimulated interest in its use as an antiproliferative agent. In preclinical studies SS analogues have inhibited the growth of a wide variety of SS-R-positive as well as SS-R-negative tumours in vivo and in vitro ${ }^{4,6,47}$. An indirect tumour growth inhibition may be achieved via the inhibition of circulating tumour growth promoting hormones (GH, insulin-like growth factor 1 , insulin) and inhibition of circulating, paracrine- and/or autocrinesecreted stimulatory growth factors. SS and its analogues can also modulate the activity of immune cells ${ }^{48}$ and potentially influence tumour blood supply; Reubi et al. ${ }^{49}$ demonstrated a high density of SS-Rs on veins in the peritumoral zone of several types of malignant tumour. A potentiation of the antiproliferative effect of octreotide has also been suggested ${ }^{50}$, but no beneficial effect of octreotide combined with tamoxifen was found in patients with metastatic breast cancer ${ }^{51}$. Critical to the direct antiproliferative effects of SS analogues is the presence of SS-Rs ${ }^{52}$. Both adenosine $3^{\prime}, 5^{\prime}$-cyclic monophosphatedependent and -independent effector mechanisms have been suggested ${ }^{5-56}$, while stimulation of phosphotyrosine phosphatase activity may play an important role in the inhibition of growth factor-stimulated cell growth ${ }^{57,58}$.

The results of clinical trials in patients with gastroenteropancreatic tumours, using SS analogues alone or in combination with interferon- $\alpha$, are rather disappointing, with a biochemical response in 77 per cent of patients with a median duration of 15 months but without any reduction in tumour size $e^{59,60}$. Clinically, octreotide has been the most commonly used SS analogue, yielding biochemical response rates of between 30 and 70 per cent but objective tumour shrinkage in less than $10-15$ per cent of patients ${ }^{5,61-64}$. Treatment with standard doses of the SS analogue lanreotide does not appear to be any better than that with standard doses of octreotide. However, tumour biopsies before and during treatment with high doses of lanreotide have indicated apoptosis in responding patients ${ }^{65,66}$. Side-effects of long-term administration of SS analogues are rare. The most relevant side-effect is the development of gallstones, which is believed to derive from the inhibition of gallbladder emptying due to the inhibition of cholecystokinin release ${ }^{67}$. The incidence of developing 
cholelithiasis and/or gallbladder sludge is reported to be between 30 and 60 per cent, and seems to be dose dependent ${ }^{68,69}$. Patients require cholecystectomy for either symptomatic disease or acute cholecystitis in 15 per cent of cases; prophylactic cholecystectomy is not indicated, unless it is performed during elective cytoreductive surgery ${ }^{69}$. Octreotide might also influence blood sugar levels in patients with diabetes mellitus.

\section{Radionuclide therapy: preclinical}

A new and fascinating application is the use of radiolabelled octreotide and other peptides for peptide receptor radionuclide therapy, henceforth referred to as radionuclide therapy. After systemic injection of $\left[{ }^{111} \mathrm{In}\right.$ $\mathrm{DTPA}^{0}$ ]octreotide, the radioligand is internalized and transported into the lysosomes by an SS-R-specific and temperature-dependent process starting with endocyto$\operatorname{sis}^{70,71}$. The radionuclide as metabolite ${ }^{111}$ In-DTPA-DPhe is not capable of passing the lysosomal membrane, resulting in a biological half-life in human tumour tissue of over $700 \mathrm{~h}^{72,73}$. ${ }^{111}$ In not only emits $\gamma$ rays, which can be visualized during scintigraphy, it also emits internal conversion and Auger electrons which have a short to medium tissue penetration $(0.02-10$ and $200-550 \mu \mathrm{m}$ respectively). Therefore, an effect on tumour cell proliferation might be expected, as the radiotoxicity of the radionuclide is very high if the DNA of the cell is within the particle range $\mathrm{e}^{7,75}$.

Three experimental animal studies have demonstrated tumour growth inhibition of solid subcutaneous tumours by radiolabelled SS analogues in animal models ${ }^{76-78}$. The authors investigated the antiproliferative effect of $\left[{ }^{111} \mathrm{In}\right.$ DTPA $^{0}$ ]octreotide on SS-R-positive, CA20948 pancreatic tumour cells in a rat liver metastases model with intraportal tumour cell injections ${ }^{79}$. Treatment with $370 \mathrm{MBq}(0.5 \mu \mathrm{g})$ $\left[{ }^{111} \mathrm{In}-\mathrm{DTPA} \mathrm{A}^{0}\right]$ octreotide was given on day 1 and/or day 8 . After 21 days the number of tumour colonies was significantly decreased by all treatment regimens compared with that in control animals; treatments on day 1 and 8 proved to be superior to single treatment on either day 1 or day 8 (Table 4). In repeated experiments, most treated animals showed no or few tumour colonies, an outcome that was not observed earlier in experiments using high doses of nonradiolabelled octreotide ${ }^{52}$. This tumour growth inhibition was predominantly due to the specific binding of $\left[{ }^{111} \mathrm{In}\right.$ DTPA $^{0}$ ]octreotide to the SS-R and not to a systemic or a secondary mechanism since pretreatment with $1 \mathrm{mg}$ octreotide before radionuclide treatment, resulting in saturation of the SS-Rs, almost completely abolished the effect of $\left[{ }^{111}\right.$ In-DTPA $\left.{ }^{0}\right]$ octreotide on SS-R-positive cells. Furthermore, radionuclide therapy had no effect on the
Table 4 Effect of radionuclide therapy with $\left[{ }^{111}\right.$ Indium-diethylenetriaminopenta-acetic acid]octreotide on somatostatin receptor-positive liver metastases

\begin{tabular}{lllll} 
& \multicolumn{3}{l}{ No. of metastases } \\
\cline { 2 - 4 } & 0 & $1-20$ & $21-100$ & $>100$ \\
Treatment & & & & 6 \\
Controls & & 4 & 1 & \\
Therapy on day 1 & 3 & 2 & \\
Therapy on day 8 & 3 & 2 & & \\
Therapy on days 1 and 8 & 3 & &
\end{tabular}

Values are number of animals with given range of metastases (5-6 animals per group), 21 days after direct injection of somatostatin receptor-positive CA20948 tumour cells into the portal vein. Peptide receptor radionuclide therapy with $370 \mathrm{MBq}(0.5 \mu \mathrm{g}){ }^{111}$ Indium-diethylenetriaminopenta-acetic acid $\left.\left({ }^{111}{ }^{1 n}-D_{T P A}\right)\right]$ octreotide was given on day 1 or 8 or on days 1 and 8 . The effect of all treatment schedules was significantly different $(P<0.01)$ from the effect of $0.5 \mu \mathrm{g}$ 'cold' $\left[{ }^{111} \mathrm{In}-\mathrm{DTPA}^{0}\right]$ octreotide on day 1 and 8 (controls). Treatment on day 1 and 8 was significantly different from treatment on day 8 alone $(P<0.05)$. No significant difference was found between the effect of treatment on day 8 or day 1 . From reference 79

growth of SS-R-negative CC531 tumours in the same experiment ${ }^{79}$. During the experiments there was no sign of toxicity in the animals and there was no histological damage to the kidney, which is the first organ to be at risk ${ }^{80}$. It was demonstrated earlier that liver regeneration after 70 per cent partial hepatectomy in this model accelerates tumour growth dramatically ${ }^{81}$. Radionuclide therapy was found completely to annihilate this tumour growth stimulation of SS-R-positive tumour cells rendering only a few tumour colonies. In an experiment without tumour $\left[{ }^{111} \mathrm{In}\right.$ $\mathrm{DTPA}^{0}$ ]octreotide did not influence liver regeneration or function, suggesting that radionuclide therapy might also be a safe option for adjuvant treatment after liver resection or arterial embolization. Although treatment with ${ }^{111} \mathrm{In}$ labelled SS analogues may be a promising option for patients with locally irresectable or disseminated gastroenteropancreatic tumours, more experiments in more advanced stages of tumour development, with different doses of $\left[{ }^{111}\right.$ In-DTPA $\left.{ }^{0}\right]$ octreotide and with other radioligands, are necessary.

Another approach in treating tumours expressing SS-R is to substitute the radionuclide with a chemotherapeutic agent. Schally's group has developed a cytotoxic SS analogue containing 2 pyrrolinodoxorubicin (AN-201), which is $500-1000$ times more potent in vitro than its parent compound ${ }^{82,83}$. By linking AN-201 to RC-121, an SS analogue, a new cytotoxic SS analogue (AN-238) was obtained. Various in vitro experiments with $\mathrm{AN}-238$ on human and rat SS-R-positive tumours have shown effective inhibition of tumour growth ${ }^{84,85}$. 


\section{Radionuclide therapy: clinical}

A phase 1 study on the side-effects and antiproliferative effect of high, multiple radiotherapeutic doses of $\left[{ }^{111} \mathrm{In}\right.$ $\mathrm{DTPA}^{0}$ ]octreotide started in $1995^{86}$. Thirty end-stage patients with mainly neuroendocrine tumours were included. After scoring tumour radioactivity uptake using scintigrams obtained $24 \mathrm{~h}$ after the injection of a diagnostic dose $(220 \mathrm{MBq})$ of $\left[{ }^{111}\right.$ In-DTPA $\left.{ }^{0}\right]$ octreotide, treatment was initiated. All patients received doses of $6-7 \mathrm{GBq}{ }^{111} \mathrm{In}$ incorporated in 40-50 $\mu \mathrm{g}\left[{ }^{111} \mathrm{In}-\mathrm{DTPA}^{0}\right]$ octreotide with intervals of at least 2 weeks between administrations. A total of eight injections was aimed at, with a possible extension to 12-14 administrations. Twenty-one patients received a total cumulative dose of at least $20 \mathrm{GBq}\left[{ }^{111} \mathrm{In}\right.$ $\mathrm{DTPA}^{0}$ ]octreotide with a maximum of $75 \mathrm{GBq}$. Of the nine patients treated with a total dose lower than $20 \mathrm{GBq}$, seven had to stop prematurely because of disease progression despite treatment and two had not finished the first course of four administrations at the time of the interim analysis. With a maximum follow-up of 26 months no major clinical side-effects were observed except for a transient decline in platelet and white blood cell count. Kidney function was influenced only slightly and not to a clinically relevant degree. Although in some patients temporary because of end-stage disease, impressive effects on clinical condition and hormone or tumour marker production were observed after the administration of high doses of $\left[{ }^{111} \mathrm{In}\right.$ DTPA $^{0}$ ]octreotide. Before the start of treatment all 21 patients had progressive disease. In eight patients treatment resulted in stable disease and in six tumour shrinkage was

Table 5 Results and characteristics of patients treated with radionuclide therapy with a minimal dose of $20 \mathrm{GBq}\left[{ }^{111} \mathrm{In}-\right.$ radiolabelled diethylenetriaminopenta-acetic acid ${ }^{0}$ octreotide

\begin{tabular}{|c|c|c|c|c|}
\hline \multirow[b]{2}{*}{ Tumour type } & \multirow[b]{2}{*}{ Total no. } & \multicolumn{3}{|c|}{ Tumour size } \\
\hline & & Reduction & Stable & Progression \\
\hline Carcinoid & 13 & 3 & 8 & 2 \\
\hline Neuroendocrine tumour & 6 & 2 & 2 & 2 \\
\hline Gastrinoma & 1 & & 1 & \\
\hline Vipoma & 1 & 1 & & \\
\hline Glucagonoma & 1 & 1 & & \\
\hline Medullary thyroid cancer & 3 & & 1 & 2 \\
\hline Papillary thyroid cancer & 1 & & 1 & \\
\hline Glomus tumour & 2 & 1 & 1 & \\
\hline Phaeochromocytoma & 2 & & 1 & 1 \\
\hline Astrocytoma & 1 & & 1 & \\
\hline Inflammatory breast cancer & 1 & & 1 & \\
\hline Total & 32 & 8 & 17 & 7 \\
\hline
\end{tabular}

All phase 1 studies. Data are from references 86-89 monitored by CT or MRI; in these patients beneficial effects occurred on hormone production and symptoms. There was a tendency towards a better result of radionuclide therapy in those whose tumours had a higher accumulation of the radioligand on the scoring scintigram. Table 5 summarizes recent results and characteristics of patients treated with radionuclide therapy with a minimum dose of $20 \mathrm{GBq}\left[{ }^{111}\right.$ In-DTPA ${ }^{0}$ octreotide ${ }^{86-91}$.

For radiotherapeutic applications, other radionuclides such as ${ }^{90} \mathrm{Y}$ and ${ }^{177} \mathrm{Lu}$ have also been proposed for coupling to SS analogues. ${ }^{90} \mathrm{Y}$, with a half-life of 2.7 days, is a pure high $\beta$ emitter with a tissue range up to $1 \mathrm{~cm}$ and ${ }^{177} \mathrm{Lu}$, with a half-life of 6.7 days, emits $\gamma$ radiation (suitable for visualization) and intermediate $\beta$ particles with approximately $1 \mathrm{~mm}$ tissue penetration. For tumours with a heterogeneous distribution of SS-Rs, ${ }^{90} \mathrm{Y}-$ and ${ }^{177} \mathrm{Lu}-$ labelled SS analogues might have extra beneficial characteristics because of an effect known as 'cross-fire'. A tumour cell lacking an SS-R might be hit by an electron coming from a neighbouring cell that has internalized the radioligand. This mechanism may lead to a high and more homogeneous radiation dose in larger parts of the tumour. Studies with these radiolabelled SS analogues are ongoing.

\section{Transfection of somatostatin receptors}

New developments in molecular biology have made it possible to transfect SS-R-negative tumour cells with an SSR gene. Susini's group has developed an approach using $\mathrm{sst}_{2}$ gene transfer for the treatment of pancreatic cancer ${ }^{92}$. By inducing the SS-R on the tumour cells, antitumour effects were obtained which might be attributed to several mechanisms. First, an autocrine negative feedback loop in which transfected tumour cells start to produce SS, which binds in an autocrine manner to the induced SS-R, may provide an inhibitory effect on tumour cell growth. Second, binding of SS to $\mathrm{sst}_{2}$ may upregulate $p 27$, a tumour suppressor gene, which leads to cell cycle arrest in the G0-G1 phase, and subsequently causes apoptosis. Local and distant bystander effects have also been noted ${ }^{93}$. The local bystander effect might be attributed in part to apoptosis. When type sst $_{2}$-positive cells undergo apoptosis, these cells release apoptotic vesicles and enzymes, which in turn might kill neighbouring cells. The distant bystander effect may be explained by a paracrine effect. SS can upregulate the expression of sst $_{1}$ on parental tumour cells, thereby rendering them sensitive to the antiproliferative effect of SS. All the abovementioned mechanisms may contribute to successful treatment of certain types of cancers with gene therapy.

Another reason why transfection of tumour cells with an SS-R gene may be beneficial involves radionuclide ther- 
apy $^{79}$. By inducing the SS-R on SS-R-negative tumours, treatment with radionuclides should be possible. Moreover, transfection of SS-R-positive tumours with an SS-R gene can increase the homogeneity of distribution of tumour cells expressing the SS-R and so increase the efficacy of therapy; the present authors are currently investigating this strategy. By using a plasmid with complementary DNA of the SS-R and G418 genes, which provides protection against the cytotoxic drug geneticin, 10 per cent of SS-Rnegative CC531 cells were cotransfected in vitro. Thereafter geneticin was added to the cells, such that non-transfected CC531 cells were eliminated, resulting in a tumour cell culture of 100 per cent transfected CC531 cells. To test expression and functional capacity of the transfected receptor, binding and internalization studies were performed. A mean of 12000 receptors per cell were expressed on the cell membrane, while internalization studies showed a high uptake of radioactive octreotide in transfected cells (66 000 versus 1200 c.p.m. in controls; $P<0 \cdot 01$ ). This effect could be blocked by 'cold' octreotide, indicating a receptorspecific transport mechanism. To evaluate growth and receptor status in vivo, in vitro transfected CC531 cells and (normal) CC531 cells were tested in a liver metastasis model by injection into the portal vein of WAG/Rij rats. Transfected CC531 cells had the same growth velocity as (normal) CC531 cells and had a high expression of SS-Rs. In future experiments, radionuclide therapy using $\beta$-emitting radionuclides, including ${ }^{90} \mathrm{Y}$ and ${ }^{177} \mathrm{Lu}$, will be tested on these in vitro transfected CC531 cells. Transfecting tumour cells with SS-Rs in combination with radionuclide therapy is a new modality in the treatment of cancer; however, it is experimental and its full potential remains to be elucidated in the near future.

\section{References}

1 Brazeau P, Vale W, Burgus R, Ling N, Butcher M, Rivier J et al. Hypothalamic polypeptide that inhibits the secretion of immunoreactive pituitary growth hormone. Science 1973; 179: 77-9.

2 Lucey MR. Endogenous somatostatin and the gut. Gut 1986; 27: 457-67.

3 Reichlin S. Somatostatin (second of two parts). N Engl 7 Med 1983; 309: 1556-63.

4 Schally AV. Oncological applications of somatostatin analogues. Cancer Res 1988; 48: 6977-85.

5 Kvols LK, Moertel CG, O'Connell MJ, Schutt AJ, Rubin J, Hahn RG. Treatment of the malignant carcinoid syndrome. Evaluation of a long-acting somatostatin analogue. N Englf Med 1986; 315: 663-6.

6 Lamberts SW, Krenning EP, Reubi JC. The role of somatostatin and its analogs in the diagnosis and treatment of tumors. Endocr Rev 1991; 12: 450-82.
7 Reubi JC, Kvols LK, Waser B, Nagorney DM, Heitz PU, Charboneau JW et al. Detection of somatostatin receptors in surgical and percutaneous needle biopsy samples of carcinoids and islet cell carcinomas. Cancer Res 1990; 50: 5969-77.

8 Reubi JC, Lamberts SW, Maurer R. Somatostatin receptors in normal and tumoral tissue. Horm Res 1988; 29: 65-9.

9 Papotti M, Macri L, Bussolati G, Reubi JC. Correlative study on neuro-endocrine differentiation and presence of somatostatin receptors in breast carcinomas. Int 7 Cancer 1989; 43: 365-9.

10 Hofland LJ, van Hagen PM, Lamberts SW. Functional role of somatostatin receptors in neuroendocrine and immune cells. Ann Med 1999; 31(Suppl 2): 23-7.

11 Kubota A, Yamada Y, Kagimoto S, Shimatsu A, Imamura M, Tsuda K et al. Identification of somatostatin receptor subtypes and an implication for the efficacy of somatostatin analogue SMS 201-995 in treatment of human endocrine tumors. 7 Clin Invest 1994; 93: 1321-5.

12 Patel YC. Molecular pharmacology of somatostatin receptor subtypes. F Endocrinol Invest 1997; 20: 348-67.

13 Hofland LJ, Liu Q, Van Koetsveld PM, ZuijderwijkJ, Van Der Ham F, De Krijger RR et al. Immunohistochemical detection of somatostatin receptor subtypes sst 1 and sst $2 \mathrm{~A}$ in human somatostatin receptor positive tumors. 7 Clin Endocrinol Metab 1999; 84: 775-80.

14 Yamada Y, Reisine T, Law SF, Ihara Y, Kubota A, Kagimoto S et al. Somatostatin receptors, an expanding gene family: cloning and functional characterization of human SSTR3, a protein coupled to adenylyl cyclase. Mol Endocrinol 1992; 6: 2136-42.

15 Reubi JC, Laissue J, Krenning E, Lamberts SW. Somatostatin receptors in human cancer: incidence, characteristics, functional correlates and clinical implications. F Steroid Biochem Mol Biol 1992; 43: 27-35.

16 Reubi JC, Horisberger U, Essed CE, Jeekel J, Klijn JG, Lamberts SW. Absence of somatostatin receptors in human exocrine pancreatic adenocarcinomas. Gastroenterology 1988; 95: 760-3.

17 van Eijck CH, Krenning EP, Bootsma A, Oei HY, van Pel R, Lindemans $\mathrm{J}$ et al. Somatostatin receptor scintigraphy in primary breast cancer. Lancet 1994; 343: 640-3.

18 Denzler B, Reubi JC. Expression of somatostatin receptors in peritumoral veins of human tumors. Cancer 1999; 85: 188-98.

19 Krenning EP, Bakker WH, Breeman WA, Koper JW, Kooij $\mathrm{PP}$, Ausema L et al. Localisation of endocrine-related tumours with radioiodinated analogue of somatostatin. Lancet 1989; i: 242-4.

20 Krenning EP, Kwekkeboom DJ, Pauwels EK, Kvols LK, Reubi JC. Somatostatin receptor scintigraphy. In: Nuclear Medicine Annual. New York: Raven Press, 1995: 1-50.

21 Valkema R, Steens J, Cleton FJ, Pauwels EK. The diagnostic utility of somatostatin receptor scintigraphy in oncology. $\mathcal{Z}$ Cancer Res Clin Oncol 1996; 122: 513-32.

22 Le Guludec D, Cadiot G, Lebtahi R, Mignon M. Detection of endocrine tumors of the digestive tract. Value and limitations 
of scintigraphy of somatostatin receptors. Presse Med 1996; 25: 677-82.

23 Gibril F, Reynolds JC, Doppman JL, Chen CC, Venzon DJ, Termanini B et al. Somatostatin receptor scintigraphy: its sensitivity compared with that of other imaging methods in detecting primary and metastatic gastrinomas. A prospective study. Ann Intern Med 1996; 125: 26-34.

24 Cadiot G, Lebtahi R, Sarda L, Bonnaud G, Marmuse JP, Vissuzaine $\mathrm{C}$ et al. Preoperative detection of duodenal gastrinomas and peripancreatic lymph nodes by somatostatin receptor scintigraphy. Groupe D'etude Du Syndrome De Zollinger-Ellison. Gastroenterology 1996; 111: 845-54.

25 Lebtahi R, Cadiot G, Sarda L, Daou D, Faraggi M, Petegnief Y et al. Clinical impact of somatostatin receptor scintigraphy in the management of patients with neuroendocrine gastroenteropancreatic tumors. 7 Nucl Med 1997; 38: 853-8.

26 Kwekkeboom DJ, van Urk H, Pauw BK, Lamberts SW, Kooij PP, Hoogma RP et al. Octreotide scintigraphy for the detection of paragangliomas. 7 Nucl Med 1993; 34: 873-8.

27 Jalil ND, Pattou FN, Combemale F, Chapuis Y, Henry JF, Peix $\mathrm{JL}$ et al. Effectiveness and limits of preoperative imaging studies for the localisation of pheochromocytomas and paragangliomas: a review of 282 cases. French Association of Surgery (AFC), and The French Association of Endocrine Surgeons (AFCE). Eur 7 Surg 1998; 164: 23-8.

28 Maurea S, Lastoria S, Caraco C, Klain M, Varrella P, Acampa $\mathrm{W}$ et al. The role of radiolabeled somatostatin analogs in adrenal imaging. Nucl Med Biol 1996; 23: 677-80.

29 Krausz Y, Rosler A, Guttmann H, Ish-Shalom S, Shibley N, Chisin $\mathrm{R}$ et al. Somatostatin receptor scintigraphy for early detection of regional and distant metastases of medullary carcinoma of the thyroid. Clin Nucl Med 1999; 24: 256-60.

30 Krenning EP, Valkema R, Kooij PP, Breeman WA, Bakker WH, deHerder WW et al. Scintigraphy and radionuclide therapy with [indium-111-labelled-diethyl triamine pentaacetic acid-D-Phe1]-octreotide. Ital 7 Gastroenterol Hep 1999; 31(Suppl 2): S219-23.

31 Adams S, Baum RP, Hertel A, Schumm-Draeger PM, Usadel $\mathrm{KH}$, Hor G. Comparison of metabolic and receptor imaging in recurrent medullary thyroid carcinoma with histopathological findings. Eur 7 Nucl Med 1998; 25: 1277-83.

32 van Eijck CH, Lamberts SW, Lemaire LC, Jeekel H, Bosman FT, Reubi JC et al. The use of somatostatin receptor scintigraphy in the differential diagnosis of pancreatic duct cancers and islet cell tumors. Ann Surg 1996; 224: 119-24.

33 Oberg K, Eriksson B. Medical treatment of neuroendocrine gut and pancreatic tumors. Acta Oncol 1989; 28: 425-31.

34 Ruszniewski P, Ramdani A, Cadiot G, Lehy T, Mignon M, Bonfils S. Long-term treatment with octreotide in patients with the Zollinger-Ellison syndrome. Eur 7 Clin Invest 1993; 23: 296-301.

35 Barrons RW. Octreotide in hyperinsulinism. Ann Pharmacother 1997; 31: 239-41.

36 Lamberts SW, Hofland LJ, van Koetsveld PM, Reubi JC, Bruining HA, Bakker WH et al. Parallel in vivo and in vitro detection of functional somatostatin receptors in human endocrine pancreatic tumors: consequences with regard to diagnosis, localization, and therapy. 7 Clin Endocrinol Metab 1990; 71: 566-74.

37 Lamberts SW, Pieters GF, Metselaar HJ, Ong GL, Tan HS, Reubi JC. Development of resistance to a long-acting somatostatin analogue during treatment of two patients with metastatic endocrine pancreatic tumours. Acta Endocrinol 1988; 119: 561-6.

38 Wynick D, Anderson JV, Williams SJ, Bloom SR. Resistance of metastatic pancreatic endocrine tumours after long-term treatment with the somatostatin analogue octreotide (SMS 201-995). Clin Endocrinol 1989; 30: 385-8.

39 de Herder WW, van der Lely AJ, Lamberts SW. Somatostatin analogue treatment of neuroendocrine tumours. Postgrad Med 7 1996; 72: 403-8.

40 Carballo F, Domínguez E, Fernández-Clavet L, MartínezPancorbo C, García A, De la Morena J. Is somatostatin useful in the treatment of acute pancreatitis? A meta-analysis. Digestion 1991; 49: 12-13.

41 Uhl W, Buchler MW, Malfertheiner P, Beger HG, Adler G, Gaus W. A randomised, double blind, multicentre trial of octreotide in moderate to severe acute pancreatitis. Gut 1999; 45: 97-104.

42 Dorta G. Role of octreotide and somatostatin in the treatment of intestinal fistulae. Digestion 1999; 60(Suppl 2): 53-6.

43 Falconi M, Sartori N, Caldiron E, Salvia R, Bassi C, Pederzoli P. Management of digestive tract fistulas. A Review. Digestion 1999; 60(Suppl 3): 51-8.

44 Buchler M, Friess H, Klempa I, Hermanek P, Sulkowski U, Becker $\mathrm{H}$ et al. Role of octreotide in the prevention of postoperative complications following pancreatic resection. Am 7 Surg 1992; 163: 125-30.

45 Hadengue A. Somatostatin or octreotide in acute variceal bleeding. Digestion 1999; 60(Suppl 2): 31-41.

46 Avgerinos A, Nevens F, Raptis S, Fevery J. Early administration of somatostatin and efficacy of sclerotherapy in acute oesophageal variceal bleeds: the European Acute Bleeding Oesophageal Variceal Episodes (ABOVE) randomised trial. Lancet 1997; 350: 1495-9.

47 Weckbecker G, Raulf F, Stolz B, Bruns C. Somatostatin analogs for diagnosis and treatment of cancer. Pharmacol Ther 1993; 60: 245-64.

48 van Hagen PM, Krenning EP, Kwekkeboom DJ, Reubi JC, Anker Lugtenburg PJ, Lowenberg B et al. Somatostatin and the immune and haematopoetic system; a review. Eur 7 Clin Invest 1994; 24: 91-9.

49 Reubi JC, Horisberger U, Laissue J. High density of somatostatin receptors in veins surrounding human cancer tissue: role in tumor-host interaction? Int 7 Cancer 1994; 56: 681-8.

50 Weckbecker G, Raulf F, Tolcsvai L, Bruns C. Potentiation of the anti-proliferative effects of anti-cancer drugs by octreotide in vitro and in vivo. Digestion 1996; 57(Suppl 1): 22-8.

51 Ingle JN, Suman VJ, Kardinal CG, Krook JE, Mailliard JA, Veeder $\mathrm{MH}$ et al. A randomized trial of tamoxifen alone or 
combined with octreotide in the treatment of women with metastatic breast carcinoma. Cancer 1999; 85: 1284-92.

52 van Eijck CH, Slooter GD, Hofland LJ, Kort W, Jeekel J, Lamberts SW et al. Somatostatin receptor-dependent growth inhibition of liver metastases by octreotide. Br 7 Surg 1994; 81: 1333-7.

53 Viguerie N, Tahiri-Jouti N, Ayral AM, Cambillau C, Scemama JL, Bastie MJ et al. Direct inhibitory effects of a somatostatin analog, SMS 201-995, on AR4-2J cell proliferation via pertussis toxin-sensitive guanosine triphosphate-binding protein-independent mechanism. Endocrinology 1989; 124: 1017-25.

54 Chou CK, Ho LT, Ting LP, Hu CP, Su TS, Chang WC et al. Selective suppression of insulin-induced proliferation of cultured human hepatoma cells by somatostatin. 7 Clin Invest 1987; 79: 175-8.

55 Hofland LJ, van Koetsveld PM, Wouters N, Waaijers M, Reubi JC, Lamberts SW. Dissociation of antiproliferative and antihormonal effects of the somatostatin analog octreotide on 7315b pituitary tumor cells. Endocrinology 1992; 131: 571-7.

56 Qin Y, Ertl T, Groot K, Horvath J, Cai RZ, Schally AV. Somatostatin analog RC-160 inhibits growth of CFPAC-1 human pancreatic cancer cells in vitro and intracellular production of cyclic adenosine monophosphate. Int 7 Cancer 1995; 60: 694-700.

57 Liebow C, Reilly C, Serrano M, Schally AV. Somatostatin analogues inhibit growth of pancreatic cancer by stimulating tyrosine phosphatase. Proc Natl Acad Sci USA 1989; 86: 2003-7.

58 Lopez F, Esteve JP, Buscail L, Delesque N, Saint-Laurent N, Vaysse $\mathrm{N}$ et al. Molecular mechanisms of antiproliferative effect of somatostatin: involvement of a tyrosine phosphatase. Metabolism 1996; 45(8 Suppl 1): 14-16.

59 Tiensuu Janson EM, Ahlstrom H, Andersson T, Oberg KE. Octreotide and interferon alfa: a new combination for the treatment of malignant carcinoid tumours. Eur 7 Cancer 1992; 28A: $1647-50$.

60 Oberg K. Advances in chemotherapy and biotherapy of endocrine tumors. Curr Opin Oncol 1998; 10: 58-65.

61 Oberg K, Norheim I, Theodorsson E. Treatment of malignant midgut carcinoid tumours with a long-acting somatostatin analogue octreotide. Acta Oncol 1991; 30: 503-7.

62 Vinik A, Moattari AR. Use of somatostatin analog in management of carcinoid syndrome. Dig Dis Sci 1989; 34(Suppl 3): 14-27S.

63 Liebow C, Lee MT, Schally A. Antitumor effects of somatostatin mediated by the stimulation of tyrosine phosphatase. Metabolism 1990; 39 (9 Suppl 2): 163-6.

64 Arnold R, Trautmann ME, Creutzfeldt W, Benning R, Benning $M$, Neuhaus $C$ et al. Somatostatin analogue octreotide and inhibition of tumour growth in metastatic endocrine gastroenteropancreatic tumours. Gut 1996; 38: 430-8.

65 Eriksson B, Renstrup J, Imam H, Oberg K. High-dose treatment with lanreotide of patients with advanced neuroendocrine gastrointestinal tumors: clinical and biological effects. Ann Oncol 1997; 8: 1041-4.
66 Imam H, Eriksson B, Lukinius A, Janson ET, Lindgren PG, Wilander $\mathrm{E}$ et al. Induction of apoptosis in neuroendocrine tumors of the digestive system during treatment with somatostatin analogs. Acta Oncol 1997; 36: 607-14.

67 Dowling RH, Hussaini SH, Murphy GM, Besser GM, Wass JA. Gallstones during octreotide therapy. Metabolism 1992; 41(9 Suppl 2): 22-33.

68 Wymenga AN, Eriksson B, Salmela PI, Jacobsen MB, Van Cutsem EJ, Fiasse RH et al. Efficacy and safety of prolongedrelease lanreotide in patients with gastrointestinal neuroendocrine tumors and hormone-related symptoms. $\mathcal{F}$ Clin Oncol 1999; 17: 1111.

69 Trendle MC, Moertel CG, Kvols LK. Incidence and morbidity of cholelithiasis in patients receiving chronic octreotide for metastatic carcinoid and malignant islet cell tumors. Cancer 1997; 79: 830-4.

70 Andersson P, Forssell-Aronsson E, Johanson V, Wangberg B, Nilsson $\mathrm{O}$, Fjalling $\mathrm{M}$ et al. Internalization of indium-111 into human neuroendocrine tumor cells after incubation with indium-111-DTPA-D-Phe1-octreotide. 7 Nucl Med 1996; 37: 2002-6.

71 De Jong M, Bernard BF, De Bruin E, Van Gameren A, Bakker $\mathrm{WH}$, Visser TJ et al. Internalization of radiolabelled [DTPA0]octreotide and [DOTA0,Tyr3] octreotide: peptides for somatostatin receptor-targeted scintigraphy and radionuclide therapy. Nucl Med Commun 1998; 19: 283-8.

72 Duncan JR, Stephenson MT, Wu HP, Anderson CJ. Indium111-diethylenetriaminepentaacetic acid-octreotide is delivered in vivo to pancreatic, tumor cell, renal, and hepatocyte lysosomes. Cancer Res 1997; 57: 659-71.

73 Krenning EP, Kwekkeboom DJ, Bakker WH, Breeman WA, Kooij PP, Oei HY et al. Somatostatin receptor scintigraphy with [111In-DTPA-D-Phe1]- and [123I-Tyr3]-octreotide: the Rotterdam experience with more than 1000 patients. Eur $\mathcal{F}$ Nucl Med 1993; 20: 716-31.

74 Howell RW. Radiation spectra for Auger-electron emitting radionuclides: report No. 2 of AAPM Nuclear Medicine Task Group no. 6. Med Phys 1992; 19: 1371-83.

75 Adelstein SJ, Merrill C. Sosman Lecture. The Auger process: a therapeutic promise? AfR Am 7 Roentgenol 1993; 160: 707-13.

76 Stolz B, Smith-Jones P, Albert R, Tolcsvai L, Briner U, Ruser $\mathrm{G}$ et al. Somatostatin analogues for somatostatin-receptormediated radiotherapy of cancer. Digestion 1996; 57(Suppl 1): 17-21.

77 Zamora PO, Gulhke S, Bender H, Diekmann D, Rhodes BA, Biersack $\mathrm{HJ}$ et al. Experimental radiotherapy of receptorpositive human prostate adenocarcinoma with $188 \mathrm{Re}-\mathrm{RC}-160$, a directly-radiolabeled somatostatin analogue. Int 7 Cancer 1996; 65: 214-20.

78 Stolz B, Weckbecker G, Smith-Jones PM, Albert R, Raulf F, Bruns $\mathrm{C}$. The somatostatin receptor-targeted radiotherapeutic [90Y-DOTA-DPhe1, Tyr3] octreotide (90Y-SMT 487) eradicates experimental rat pancreatic CA 20948 tumours. Eur 7 Nucl Med 1998; 25: 668-74.

79 Slooter GD, Breeman WA, Marquet RL, Krenning EP, van 
Eijck CH. Anti-proliferative effect of radiolabelled octreotide in a metastases model in rat liver. Int 7 Cancer 1999; 81: 767-71.

80 Krenning EP, Kooij PP, Pauwels S, Breeman WA, Postema PT, De Herder WW et al. Somatostatin receptor: scintigraphy and radionuclide therapy. Digestion 1996; 57(Suppl 1): 57-61.

81 Slooter GD, Marquet RL, Jeekel J, Ijzermans JN. Tumour growth stimulation after partial hepatectomy can be reduced by treatment with tumour necrosis factor alpha. Br F Surg 1995; 82: 129-32.

82 Nagy A, Schally AV, Halmos G, Armatis P, Cai RZ, Csernus V et al. Synthesis and biological evaluation of cytotoxic analogs of somatostatin containing doxorubicin or its intensely potent derivative, 2-pyrrolinodoxorubicin. Proc Natl Acad Sci USA 1998; 95: 1794-9.

83 Nagy A, Armatis P, Schally AV. High yield conversion of doxorubicin to 2-pyrrolinodoxorubicin, an analog 500-1000 times more potent: structure-activity relationship of daunosamine-modified derivatives of doxorubicin. Proc Natl Acad Sci USA 1996; 93: 2464-9.

84 Koppan M, Nagy A, Schally AV, Arencibia JM, Plonowski A, Halmos G. Targeted cytotoxic analogue of somatostatin AN238 inhibits growth of androgen-independent Dunning R3327-AT-1 prostate cancer in rats at nontoxic doses. Cancer Res 1998; 58: 4132-7.

85 Kahan Z, Nagy A, Schally AV, Hebert F, Sun B, Groot K et al. Inhibition of growth of MX-1, MCF-7-MIII and MDA-MB231 human breast cancer xenografts after administration of a targeted cytotoxic analog of somatostatin, AN-238. Int 7 Cancer 1999; 82: 592-8.

86 Krenning EP, de Jong M, Kooij PP, Breeman WA, Bakker WH, de Herder WW et al. Radiolabelled somatostatin analogue(s) for peptide receptor scintigraphy and radionuclide therapy. Ann Oncol 1999; 10(Suppl 2): S23-9.

87 Caplin ME, Mielcarek W, Buscombe JR, Jones AL, Croasdale PL, Cooper MS et al. Toxicity of high-activity ${ }^{111} \mathrm{In}$-octreotide therapy in patients with disseminated neuroendocrine tumours. Nucl Med Commun 2000; 21: 97-102.

88 Fjalling M, Andersson P, Forssell-Aronsson E, Gretarsdottir J, Johansson V, Tisell LE et al. Systemic radionuclide therapy using indium-111-DTPA-D-Phe1-octreotide in midgut carcinoid syndrome. 7 Nucl Med 1996; 37: 1519-21.

89 Tiensuu Janson E, Eriksson B, Oberg K, Skogseid B, Ohrvall $\mathrm{U}$, Nilsson $\mathrm{S}$ et al. Treatment with high dose [(11) In-DTPAD-PHE1]-octreotide in patients with neuroendocrine tumors; evaluation of therapeutic and toxic effects. Acta Oncol 1999; 38: 373-7.

90 Wiseman GA, Kvols LK. Therapy of neuroendocrine tumors with radiolabeled MIBG and somatostatin analogues. Semin Nucl Med 1995; 25: 272-8.

91 McCarthy KE, Woltering EA, Espenan GD, Cronin M, Maloney TJ, Anthony LB. In situ radiotherapy with $111 \mathrm{In}-$ pentetreotide: initial observations and future directions. Cancer J Sci Am 1998; 4: 94-102.

92 Rauly I, Saint-Laurent N, Delesque N, Buscail L, Esteve JP, Vaysse $\mathrm{N}$ et al. Induction of a negative autocrine loop by expression of sst 2 somatostatin receptor in NIH 3 T3 cells. 7 Clin Invest 1996; 97: 1874-83.

93 Rochaix P, Delesque N, Esteve JP, Saint-Laurent N, VoightJJ, Vaysse $\mathrm{N}$ et al. Gene therapy for pancreatic carcinoma: local and distant antitumor effects after somatostatin receptor sst2 gene transfer. Hum Gene Ther 1999; 10: 995-1008. 